\title{
Distribution of radon activity in the atmosphere above Wzgórza Niemczańsko-Strzelińskie (South-West Poland) and its dependence on uranium and thorium content in the underlying rock and indirect ground basement
}

\author{
Agnieszka Anna Ochmann \\ Institute of Geological Sciences Wrockaw University, Wrockaw, Poland
}

\begin{abstract}
Radon activity in the atmosphere and its behavior in the environment have been investigated using LR-115 nuclear track detector. The complex geological structure of Wzgórza Niemczańsko-Strzelińskie (south-west Poland) enabled this problem to be studied in various geological conditions. The eU and eTh content in rocks and soil was measured by gamma-spectrometer GR-320. Uranium content of bedrock reached its maximum value of $15 \mathrm{ppm}$ in the case of quartz-graphite schist. Thorium reached its maximum value of $35 \mathrm{ppm}$ in the case of granodiorite. Radon activity was measured by means of long-term exposure of LR-115. The mean value of atmospheric radon activity was $21 \mathrm{Bqm}^{-3}$ in the air $2 \mathrm{~m}$ above the ground surface. The highest radon activities were measured in the area of granite and quartz-graphite schist outcrops and in the area of mylonitic rocks of the Niemcza Zone. Radon activity in close to ground cup detectors varies from 25 to $300 \mathrm{Bqm}^{-3}$, these values depend on uranium and thorium content in indirect ground basement (soil and weathered rocks). Not only uranium and thorium content but also rock disintegration due to tectonic events (shear zones) influenced atmospheric radon activity. Seasonal variation is not strong, although higher values were measured in the autumn-winter period.
\end{abstract}

Key words radon - atmosphere - uranium - thorium - rock

\section{Introduction}

Radon is released into the atmosphere mainly from soils and underlying rocks, from ground

Mailing address: Dr. Agnieszka Anna Ochmann, Institute of Geological Sciences Wrocław University, pl. M. Borna 9, 50-204 Wrockaw, Poland; e-mail: ochmannn@yahoo.com waters (especially thermal ground waters), but also from oceans, natural gases, caves and mines (Gesell, 1983; Khatir Sam and Holm, 1995; Lozano et al., 2000; Jha et al., 2001; Papastefanou, 2001). Spatial variation of outdoor radon activity and its dependence on the geological conditions, on the type of cover of Earth surface (ocean, ice cap or snow cover) and on the variations in soil moisture (Grasty, 1991) was investigated in many areas worldwide (Gesell, 1983; Gundersen, 1991). There is a large number of measurements of radon activity in the air above the ground surface, but due to the application of different methods, the results are not compara- 
ble. Gesell (1983) compared the data from the area of United States, where the average radon activity in the air varies between 4-15 $\mathrm{Bqm}^{-3}$. In Canada outdoor radon activity, measured by one of the passive methods with an exposure period of 3 months, varied from $11 \mathrm{Bqm}^{-3}$ to $67 \mathrm{Bqm}^{-3}$ (the mean value for Manitoba is $59 \mathrm{Bqm}^{-3}$ and Saskatchewan - $61 \mathrm{Bqm}^{-3}$ ) (Grasty, 1991). According to UNSCEAR (1983 fide Wilkening 1990) the typical radon activity in the air above the ground surface averages $10 \mathrm{Bqm}^{-3}$.

The aim of this investigation was to enrich the knowledge of radon behavior and to construct a map of spatial variation of radon activity on the eastern area of Foresudetic Block.

\section{Geological setting}

Wzgórza Niemczańsko-Strzelińskie are located in the eastern part of the Foresudetic bloc (SW part of Poland). This area includes the periphery of the Sowie Góry Block, Niemcza Zone, metamorphic of Niemcza-Kamieniec Zabkowicki, which is extended on the NE from the Niemcza Zone, and a crystalline massif of Wzgórza Strzelińskie (fig. 1). The North-East part of Sowie Góry Block is composed mainly of paragneisses and migmatic gneisses. In the gneisses small bodies of amphibolite, gabbro and serpentinite are inserted (Dziedzicowa, 1987). In the vicinity of the boundary of Niemcza Zone there are intrusions of quartz monzodiorite, which belongs to the plutonic rocks of Niemcza Zone (Dziedzicowa, 1987).

Niemcza zone is extended along the east edge of Góry Sowie Block. It is the zone of dislocation of the mass of rocks and is built of mylonites originated from deformations of gneisses of Góry Sowie (Scheumann, 1937 fide Dziedzicowa, 1987; Mazur et al., 1995). The mylonitic rocks include the small bodies of amphibolites, quartz-graphite schist, the enclaves of gneisses and intrusions of plutonic rocks (Mazur et al., 1995). In the south part of Niemcza Zone there are vast outcrops of serpentinite and gabbro (Puziewicz and Radkowska, 1990).

The eastern edge of Niemcza Zone adjoins the series of mica schist or more general series of metamorphic rocks. This area is known as a metamorphic of Niemcza-Kamieniec Ząbkowicki and its contact with the crystalline massif of Wzgórza Strzelińskie (Strzelińskie Hills) in the eastern part is covered with Quaternary sediments (Dziedzicowa, 1966). Metamorphic of Niemcza-Kamieniec Zabkowicki is built mainly of mica schist with the inserts of quartz-feldspathic schist, quartz-graphite schist, amphibolites and marbles (Dziedzicowa, 1966).

Between the metamorphic of Niemcza-Kamieniec Ząbkowicki and Wzgórza Strzelińskie, near Górka Sobocka village, there are outcrops of granite intrusion and its southern metamorphic cover - gneisses of Wzgórza Lipowe (Lipowe Hills) (Wojnar, 1977; Bartz and Puziewicz, 1999). According to Oberc-Dziedzic and Szczepanski (1995) the granite from Górka Sobocka is the westernmost part of the crystalline massif of Wzgórza Strzelińskie.

The series of crystalline rocks of the Wzgórza Strzelińskie massif can be divided into four groups (Oberc-Dziedzic, 1991): gneisses, the elder schist series, the younger schist series and plutonic rocks. The most common are gneisses. The rocks of the elder schist series (amphibolites, mica schist, limestone and marbles) appear in gneisses and are crimped with the rocks of younger series. The younger schist series, named Jeglowa series, is composed of quartzite, quartz-sericite schist, mica-sillimanite-quartz schist. The youngest group of rocks are plutonic rocks: quartz diorite, tonalitie, granodiorite and granite. Granite predominates in the northen part of massif (Oberc-Dziedzic, 1991). On the whole area of investigation there are the intrusions of Tertiary basalts.

Complex geological structure of this area, a wide variety of types of rocks and the presence of tectonic zone between Sowie Góry Block and crystalline massif of Wzgórza Strzelińskie (Mazur et al., 1995), enabled the discussed problem to be studied in various geological conditions.

\section{Methods}

The fundamental equipment of this investigation was the LR-115 detector (production of Kodak), which is one of many types of solid 


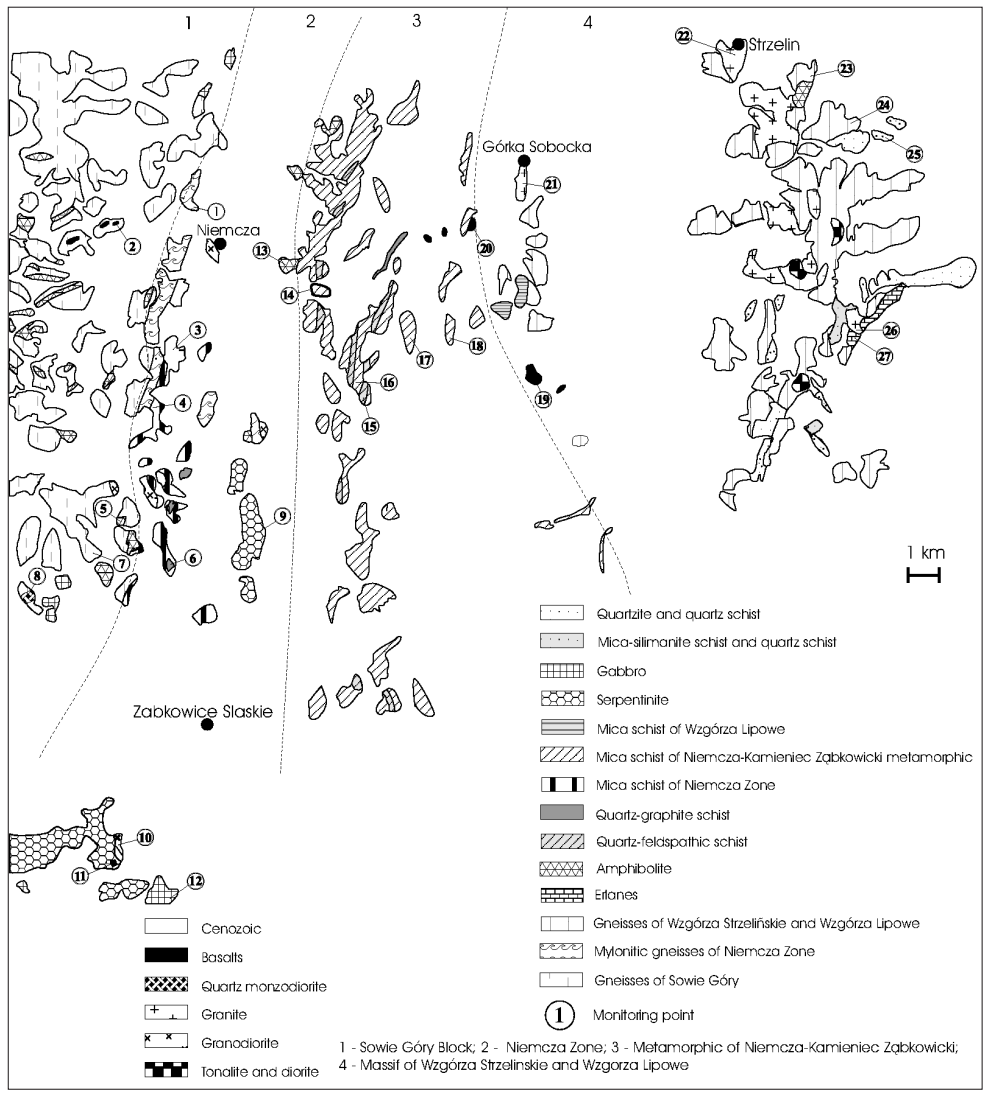

Fig. 1. Geological scheme of Wzgórza Niemczańsko-Strzelińskie (scheme prepared on the basis of the geological maps made by Badura, Berezowska, Cwojdzinski, Dziemianczuk, Gawronski, Gazdzik, Jerzmanski, Oberc, Trepka, Walczak-Augustyniak, Wòjcik).

state nuclear track detectors. The application of solid state nuclear track detectors is based on the creation of structural defects on the sensitive surface of the detector due to alpha-particle hit against it (Fleischer et al., 1965). The structural defects were enlarged during the process of etching, which enabled us to observe them even at slight magnification.

A LR-115 detector was used for measuring the radon activity in the air (both in the open air and inside of a closed can). According to the information of its manufacturer, the LR-115 detector records the alpha-particles in a range of 1.2$4.8 \mathrm{MeV}$, meaning that the alpha-particles emitted in a well-defined distance from the detector could be registered. This characteristic facilitates the elimination of recording alpha-particles emitted from the solid products of radon decay.

In order to carry out the measurements of radon activity in the outdoor air, the detectors were fixed to the inner surface of a black plastic cup (of $8 \mathrm{~cm}$ diameter). The plastic cups provided shelter from the sun light and precipitations. We chose 27 monitoring points were situated on the outcrops of the different types of rocks. Each monitoring point consisted of 4 cups fixed $2 \mathrm{~m}$, $1 \mathrm{~m}, 0.5 \mathrm{~m}$ and $0.05 \mathrm{~m}$ above the ground surface (fig. 2a,b). The higher the level above the ground surface where the detector was fixed the more representative the measure was for the more ex- 


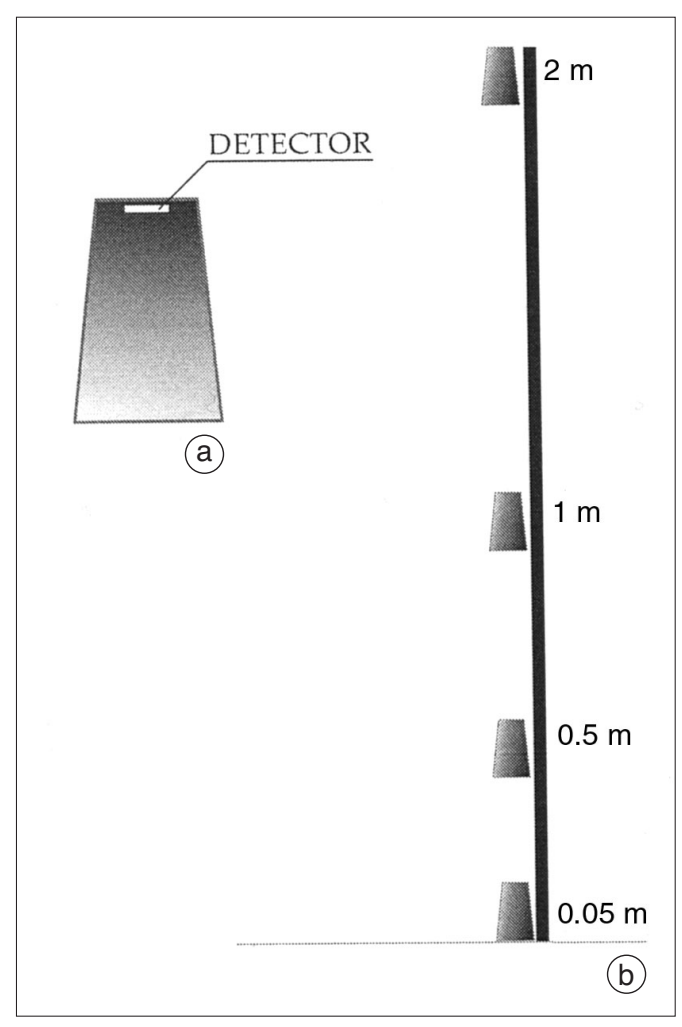

Fig. 2a,b. The measurements of radon activity in the outdoor air, a) a plastic cup with detector; b) diagram presenting the construction of the monitoring point.

tensive area. Furthermore, detectors situated $0.05 \mathrm{~m}$ above the ground registered thoron $\mathrm{Rn}^{220}$ beside the radon $\mathrm{Rn}^{222}$. The time of exposure was 6 months, twice a year: October-March (autumnwinter period) and April-September (spring-summer period). A long measurement period enables us to obtain the average values for the time of exposure and reduces the effect of diurnal fluctuations of pressure and temperature. The two sets of measurements were repeated the following year and the values obtained were similar to these which had been taken the year before.

The radon activity in the outdoor air was calculated dividing the number of traces on $1 \mathrm{~cm}^{2}$ of the detector surface by the number of days of exposure and the result obtained multiplied by the calibration coefficient (in case of the atmospher- ic air it is 13.8), this model was elaborated by Srivastawa et al. (1995).

The LR-115 detector was also used during the measurement of the radon emanation from different types of rocks from the investigated area. To measure the radon emanation a modified method of the «can technique» was applied. The «can technique» was developed by Alter and Prize (1974 fide Azam et al., 1995) and then applied with some modification, among others, by Karamadoust (1988), Azam et al. (1995) and Solecki (1999).

The basis of this method is that the total amount of radon in the investigated material consists of two parts, one - the atoms of radon stuck in the mineral crystals, the other - the radon atoms free to migrate in the interstitial spaces. The second part of radon atoms is the part which can get out of the rock material, enter the air above and could be registered by the detector. The ratio of these parts is defined by the emanation coefficient. The emanation coefficient was calculated introducing the total radium activity (content) $C_{t \mathrm{Ra}}$ and effective radium activity $C_{e \mathrm{Ra}}$

$$
k_{e}=C_{e \mathrm{Ra}} / C_{t \mathrm{Ra}} .
$$

The total radium activity $C_{t \mathrm{Ra}}$ is the total amount of radon in the rock material calculated on the basis of gamma-spectrometric analysis of radium activity. In this case the analysis was made by Radiometric Laboratory of GIG in Katowice, using semi-conductor detector HPGe, according to the Polish norm PN-89/Z-70073. The effective radium content $C_{e \mathrm{Ra}}$ is the fraction of radium which corresponds to the part of radon which has emanated from the sample. Effective radium activity is expressed in $\mathrm{Bq} / \mathrm{kg}$ unit and can be calculated from the equation

$$
C_{e \mathrm{Ra}}=\frac{\rho V}{K M T_{e}}
$$

where $\rho$ is the track density on $\mathrm{cm}^{2}$ of the detector surface, $V$ the volume of free space in the can, $K$ a calibration constant $\left(0.0245\right.$ track on $\mathrm{cm}^{2}$ in one day), $M$ the mass of sample in $\mathrm{kg}$ and $T_{e}$ the time of exposure in days (Azam et al., 1995).

Crushed rock material (grain size of 3.5$1 \mathrm{~cm}$ ) was closed in a hermetic can of the known 
volume. On the inner surface of the cap, there was fixed a detector to register the alpha particles of radon in the air above the sample of rock (fig. 3). The important element is to start exposure after stabilization of the secular equilibrium between $\mathrm{Ra}^{226}$ and $\mathrm{Rn}^{222}$. The equilibrium (of $98 \%$ ) between them stabilizes after 3 weeks in the closed space. Because of this period of stabilization, 3 weeks after closing the can, the detector was covered by metal plate, which was held by a magnet from outside of the can. After this period the metal plate was removed by taking away the magnet and the detector starts to be exposed. This is a modification of the Azam method introduced by Solecki (1999). The detector mainly registers the alpha particles which come from the decay of $\mathrm{Rn}^{222}$ and not from $\mathrm{Rn}^{220}$. Taking into account diffusion coefficients of radon in the air and in the crushed rock material, the half-life time of the thoron $\mathrm{Rn}^{220}$ and the distance between the detector and the surface of the sample, it was estimated that alpha particles of thoron could be registered in $10 \%$. The ema-

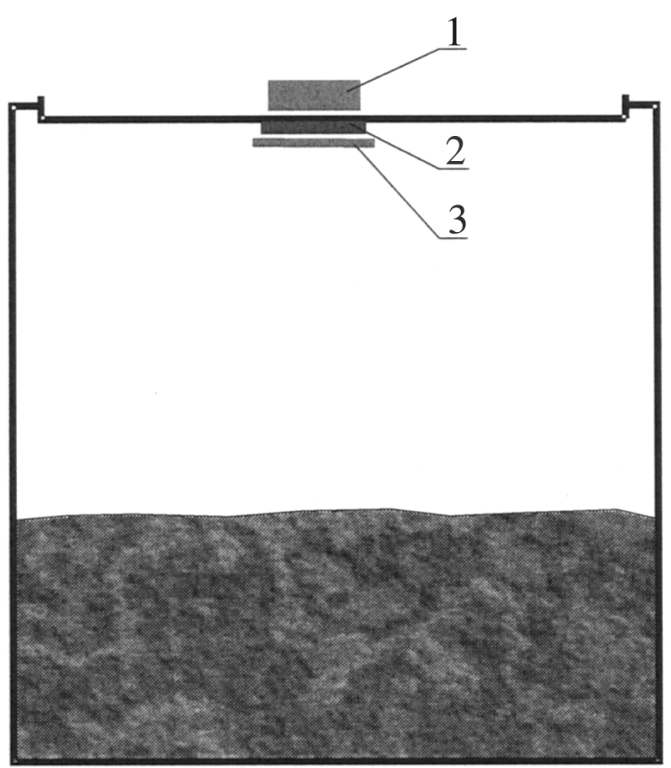

Fig. 3. The instrument for measuring radon emanation from the rock material by «can technique» method; 1 - magnet, 2 - detector, 3 - metal plate. nation coefficients of 14 different types of rocks were measured and estimated. Moreover the emanation coefficient was measured for a grain size smaller than $1 \mathrm{~cm}$ and for a moisture content of $13 \%$ and $24 \%$ wt for each type of rock. These variations of conditions changed the $k_{e}$ values but the relative differences of $k_{e}$ between the different types of rocks remained the same. In this paper $k_{e}$ values are presented which were obtained for dry rock material of grain size of $3.5-1 \mathrm{~cm}$.

The field measurements of the uranium and thorium content in rocks and soil were performed using gamma-spectrometer GR-320. The gamma-spectrometer GR-320 is equipped with a detector, with a source $\mathrm{Cs}$ of $0.5 \mathrm{mCi}$ $(18.5 \mathrm{kBq})$. The gamma-spectrometer GR-320 measures contents of $\mathrm{Bi}^{214}$ and $\mathrm{Tl}^{208}$ and on this basis, it estimates the contents of $\mathrm{U}^{238}$ and $\mathrm{Th}^{232}$. Therefore the results are presented as an equivalent content of uranium (eU) and thorium (eTh). A few zero values of measurements obtained on the outcrops of gabbro and serpentinites prove that the cosmic radiation does not influence the results of measurements.

The 29 sets of measurements (in each place - 30 single measurements, each one lasting 300s) were collected above the outcrops of different type of rocks and above the soils which cover them.

\section{Results}

\subsection{The eU and eTh content in soil and underlying rocks}

The mean eU contents in the rocks of investigated area vary from values close to zero (gabbro, serpentinite) up to $12 \mathrm{ppm}$, in the quartzgraphite schist in the south part of Niemcza Zone (fig. 4). The quartz-graphite schist which crops out in the north part of metamorphic of Niemcza-Kamieniec Zabkowicki, contains 7 ppm eU. The mean values for granitoides are 3-6 ppm eU, in mica schist of metamorphic of NiemczaKamieniec Ząbkowicki and schist of Wzgórza Lipowe the measured contents are 2-4 ppm eU. A relatively high value was obtained for basalt in the north-east part of the metamorphic of Niem- 


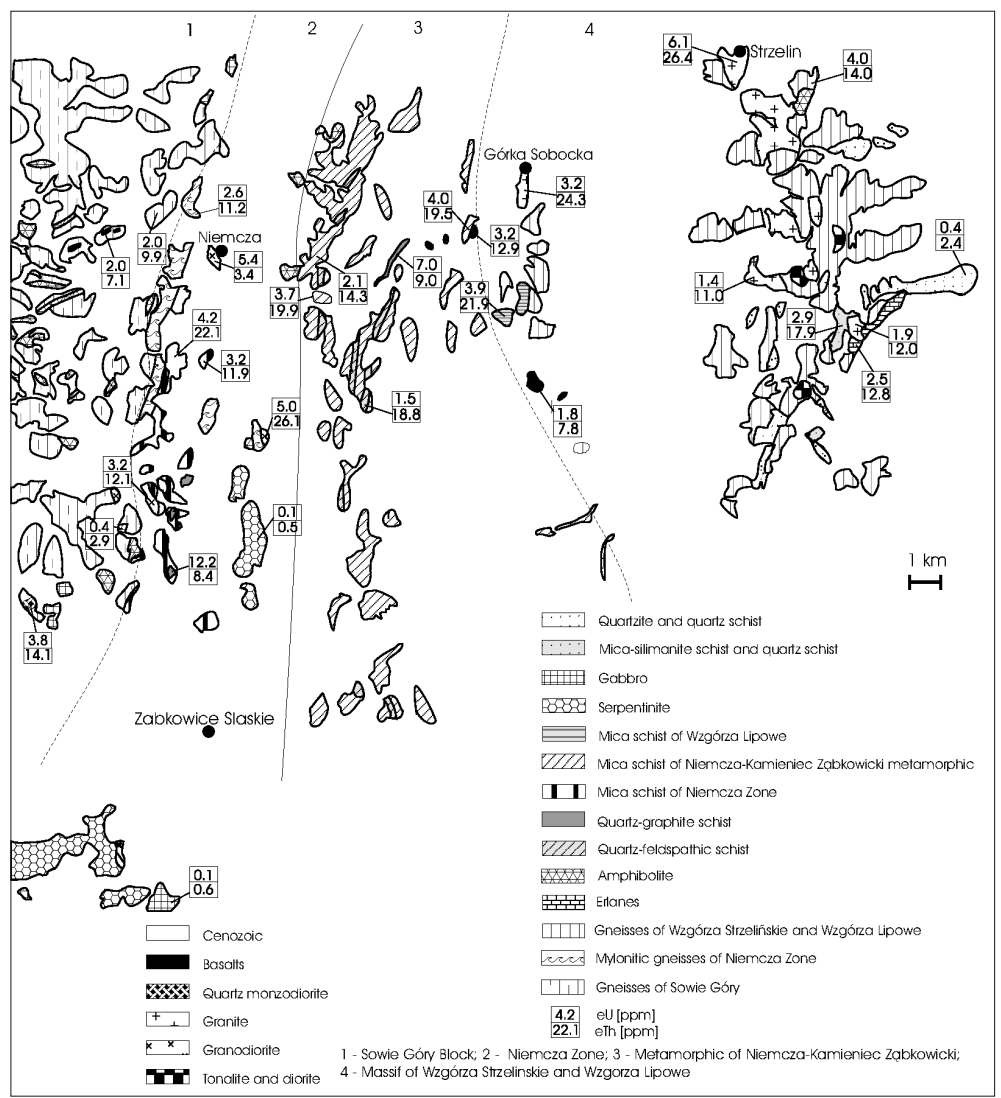

Fig. 4. The mean eU and eTh contents in the rocks of Wzgórza Niemczańsko-Strzelińskie.

cza-Kamieniec Zabkowicki - $3.2 \mathrm{ppm}$. The lowest values of uranium content were measured on amphibolites, quartzite, quartz-feldspathic schist and some basalts.

The thorium content has a decisive impact the thoron activity in the environment. The relatively high eTh contents ( $>20 \mathrm{ppm})$ were measured on the outcrops of some granite and schist of Wzgórza Lipowe (fig. 4). The highest mean value $-32 \mathrm{ppm}$, was found on granodiorite near Niemcza. The slightly lower thorium contents (20-15 ppm) were recorded in quartz-feldspathic schist of metamorphic of Niemcza-Kamieniec Ząbkowicki, mica schist of Wzgorza Lipowe and mica-sillimanite schist in south part of Wzgorza Strzelinskie. The high value eTh of the basalt in the north-east part of the metamorphic of Niemcza-Kamieniec Zabkowicki - 12.9 ppm is noteworthy.

The uranium and thorium content in soil usually corresponds to the contents in the underlying rocks. In most places the eU and eTh contents in soil (mean values: 2 ppm eU and 8 ppm eTh) are slightly reduced in relation to the contents in underlying rocks (mean: $3 \mathrm{ppm}$ eU and $12 \mathrm{ppm}$ eTh), but not in every place. On the areas composed of amphibolite, serpentinite, gabbro and quartzite the values measured on soil are higher than the values measured on the underlying rocks. It could be explained by the presence of loess material in the soil, which contains, after Solecki (2000), 2-3 ppm eU and about 10 ppm eTh. 


\subsection{The emanation coefficient of the samples of selected rocks}

Emanation coefficient $\left(k_{e}\right)$ is interpreted as a ratio of the amount of radon that emanated to the air above the sample to the whole radon which was generated in the sample. Emanation coefficient is a feature of the material and quantifies the ability of this material to emanate radon-gas.

The emanation coefficient of samples of 14 selected rocks vary in the range 0.003-0.13 (table I). According to UNSCEAR, the emanation coefficient varies in range of $0.01-0.8$ (1988 fide Robé and Labed, 1995; Markkanen and Arvela, 1992). The emanation coefficients of investigated rocks fit in the lower range of the

Table I. Emanation coefficient $\left(k_{e}\right)$ and effective $\mathrm{Ra}^{226}$ activity of selected rocks from investigated area.

\begin{tabular}{lcc}
\hline \hline Type of rock & $k_{e}$ & $\begin{array}{c}C_{e \mathrm{R}{ }^{226}} \\
{[\mathrm{~Bq} / \mathrm{kg}]}\end{array}$ \\
\hline Gabbro & 0.01 & 0.03 \\
Serpentine & 0.03 & 0.13 \\
Quartzite (Wzgórza Strzelińskie) & 0.07 & 0.45 \\
amphibolite (NE part & 0.06 & 0.80 \\
of Sowie Góry) & & \\
Basalt (E periphery of Góry & 0.007 & 0.26 \\
Sowie) & & \\
Basalt (metamorphic of Niemcza- & 0.003 & 0.17 \\
-Kamieniec Ząbkowicki) & & \\
Basalt (S part of Wzgórza & 0.003 & 0.08 \\
Lipowe) & & \\
Quartz-feldspathic schist & 0.13 & 3.39 \\
(metamorphic of Niemcza & & \\
-Kamieniec Ząbkowicki) & & \\
Quartz-graphite schist & 0.11 & 6.80 \\
(Niemcza Zone) & & \\
Gneisses (Wzgórza Strzelińskie) & 0.01 & 0.55 \\
Quartz monzodiorite & 0.01 & 0.51 \\
(NE part of Sowie Gory) & & \\
Granodiorite (Niemcza Zone) & 0.06 & 4.43 \\
Granite (Górka Sobocka) & 0.09 & 5.25 \\
Granite (Strzelin) & 0.03 & 1.90 \\
\hline
\end{tabular}

values published by UNSCEAR. The lower emanation coefficients were measured for basalts and the highest values of emanation coefficient were obtained for quartz-feldspathic schist, quartz-graphite schist and granite (Górka Sobocka). Solecki (1999) measured for the metamorphic schist an emanation coefficient of 0.29 . The higher emanation coefficient of metamorphic schist than that of the magmatic rocks could be explained by the textures of metamorphic schist, which were formed as a result of numerous transformations and deformations. Therefore it could be presumed that the migration inside these rocks will be faster than in the solid magmatic rock.

Effective radium activity (content) $\left(C_{e \text { Ra }}\right)$ quantifies the radon that come out to the atmosphere from the definite quantity of crushed rock. Effective radium activity is the result of the total activity of $\mathrm{Ra}^{228}$ and $\mathrm{Ra}^{226}$ in rock and the emanation coefficient of this rock. The measurements inside the closed can partially include the thoron emanation, however in the atmosphere the presence of thoron is limited up to the height of $30-40 \mathrm{~cm}$. Therefore in the case of atmospheric radon the effective $\mathrm{Ra}^{226}$ activity should by taken in consideration. The effective $\mathrm{Ra}^{226}$ activity for the investigated samples is shown in the last column of table I.

\subsection{Atmospheric radon activity in the air $2 \mathrm{~m}$ above the ground surface}

The radon activity distribution above the area of Wzgórza Niemczańsko-Strzelińskie is illustrated in fig. 5, the values are year-average. The highest radon activity, above 20 $\mathrm{Bq} \mathrm{m}^{3}$, is observed above the area of the outcrops of mylonite of Niemcza Zone, where the maximum values were measured above the outcrops of mylonitic gneisses, granodiorite and quartz-graphite schist. Another area of high values is the region of Górka Sobocka, Wzgórza Lipowe and North-West part of Wzgórza Strzelińskie, with the maximum values above the outcrops of granites near Gorka Sobocka and Strzelin. These two geological situations of the higher radon activity in the atmosphere demonstrate the two general factors 


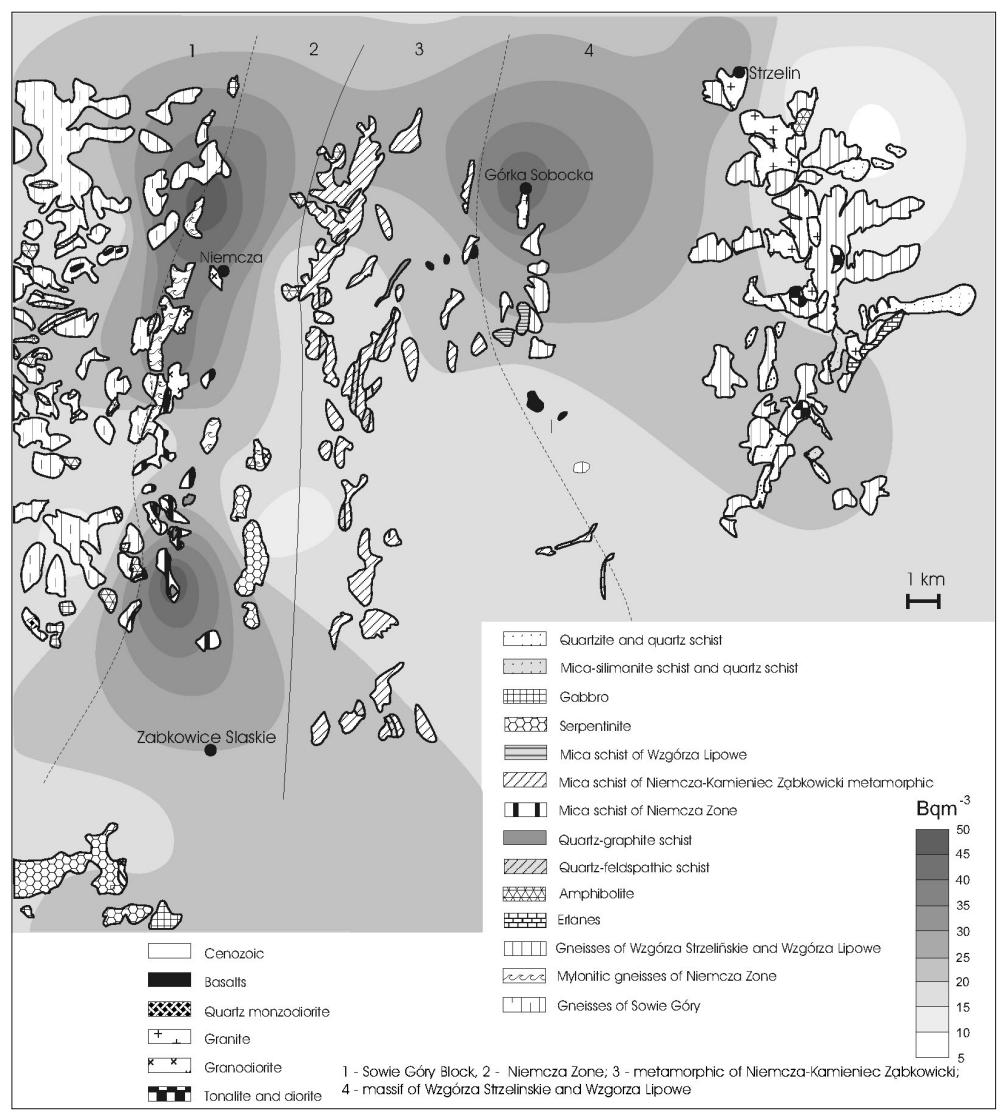

Fig. 5. Atmospheric radon activity distribution above the area of Wzgórza Niemczańsko-Strzelińskie.

that influence the radon exhalation: uranium/ radium content in the rocks and their emanation coefficient. The influence of the high contents of uranium in rocks on the radon activity in the atmosphere is obvious. Much more interesting seems to be the influence of the mylonitisation, fracturating and weathering of rocks in the tectonic zone, which can be observed above the Niemcza Zone. The increased migration of radon from fractured and weathered rocks was described among others by Gates et al. (1990), Ball et al. (1991), Gundersen (1991), Dubois et al. (1995) and Ciężkowski and Przylibski (1997). Faults and cracks increase the surface of contact between rock and ground water, what promotes the pos- sibility of radon migration too (Ball et al., 1991; Strzelecki and Wolkowicz, 1993).

The mean value of atmospheric radon activity, measured $2 \mathrm{~m}$ above the ground, on the area of Wzgórza Niemczańsko-Strzelińskie was 21 $\mathrm{Bqm}^{-3}$. This value corresponds to the radon activity measured above the central mountainous areas of the USA. The mean radon activity in the atmosphere on the area of USA varies in the range of 4-15 $\mathrm{Bqm}^{-3}$, on the Colorado Plateau these values reach 18.5-27.8 $\mathrm{Bqm}^{-3}$ (Gesell, 1983). In Canada outdoor radon activity measured $3 \mathrm{~m}$ above the ground surface reached the mean values for the provinces of Manitoba 59 $\mathrm{Bqm}^{-3}$ and Saskatchewan $61 \mathrm{Bqm}^{-3}$ (Grasty, 1991). 


\subsection{Radon activity in the air close to ground, $0.05 \mathrm{~m}$ above the ground surface}

The year-average values of radon activity close to the ground are shown in table II. The values are not interpolated over the whole

Table II. Radon activity in the air close to the ground above the outcrops of different rocks.

\begin{tabular}{|c|c|c|}
\hline $\begin{array}{l}\text { Number of } \\
\text { monitoring } \\
\text { point } \\
\text { (fig. 1) }\end{array}$ & $\begin{array}{l}\text { Type of } \\
\text { underlying } \\
\text { rock }\end{array}$ & $\begin{array}{l}\mathrm{Rn} \text { activity } \\
.05 \mathrm{~m} \text { above } \\
\text { the ground } \\
{\left[\mathrm{Bqm}^{-3}\right]}\end{array}$ \\
\hline 1 & $\begin{array}{l}\text { Mylonitic gneisses } \\
\text { of Niemcza Zone }\end{array}$ & 193 \\
\hline 2 & Basalt & 171 \\
\hline 3 & Granodiorite & 303 \\
\hline 4 & $\begin{array}{c}\text { Mica schist } \\
\text { of Niemcza Zone }\end{array}$ & 90 \\
\hline 5 & Amphibolite & 118 \\
\hline 6 & Quartz-graphite schist & 52 \\
\hline 7 & Gneisses of Sowie Góry & 25 \\
\hline 8 & Quartz monzodiorite & 66 \\
\hline 9 & Serpentinite & 45 \\
\hline 10 & Granodiorite & 212 \\
\hline 11 & Serpentinite & 37 \\
\hline 12 & Gabbro & 85 \\
\hline 13 & Amphibolite & 165 \\
\hline 14 & Mica schist & 67 \\
\hline 15 & Quartz-feldspathic schist & 131 \\
\hline 16 & Mica schist & 137 \\
\hline 17 & Mica schist & 180 \\
\hline 18 & Mica schist & 155 \\
\hline 19 & Basalt & 87 \\
\hline 20 & Basalt & 101 \\
\hline 21 & Granite & 240 \\
\hline 22 & Granite & 200 \\
\hline 23 & $\begin{array}{c}\text { Gneisses } \\
\text { of Wzgórza Strzelińskie }\end{array}$ & 48 \\
\hline 24 & $\begin{array}{c}\text { Gneisses } \\
\text { of Wzgórza Strzelińskie }\end{array}$ & 47 \\
\hline 25 & Quartzite and quartz schist & 40 \\
\hline 26 & Granite & 145 \\
\hline 27 & Erlanes & 75 \\
\hline
\end{tabular}

area because this parameter varies strongly, depending on the exhalation from the limited local ground. Moreover, because of the way the cups with detectors are positioned (they were placed directly on the ground), the measurements were not influenced by dispersion in the atmosphere. The measurements carried out close to the ground include $\mathrm{Rn}^{222}$ and $\mathrm{Rn}^{220}$, so the radon activity values are influenced by both uranium and thorium content in soil and underlying rocks.

The highest values of radon activity ( $>200$ $\mathrm{Bqm}^{-3}$ ) in air close to the ground were measured on granodiorite and granite, a little lower values $\left(100-200 \mathrm{Bqm}^{-3}\right)$ were measured on mylonitic gneisses of Niemcza Zone, on mica schist and quartz-feldspathic schist of metamorphic of Niemcza-Kamieniec Zabkowicki and on some basalts. The high values of radon activity are caused by the relatively high uranium and thorium content in soil (2-3 ppm eU and 7-18 ppm eTh) and underlying rocks (3-6 ppm eU and 11$26 \mathrm{ppm}$ eTh) in these places. The lowest activities $\left(25-45 \mathrm{Bqm}^{-3}\right)$ were measured on serpentinite and gneisses of Góry Sowie, where the uranium and thorium contents are: close to zero for eU and 2$3 \mathrm{ppm}$ eTh. The relatively low radon activity of $52 \mathrm{Bqm}^{-3}$ on quartz-graphite schist, where the contents of eU and eTh in rock are $13 \mathrm{ppm}$ and $6.6 \mathrm{ppm}$ respectively, results from the unavoidable location of the detector outside of the old quarry, near the gneiss outcrops. The high values of radon activity in the air in relation to the low uranium and thorium contents in underlying rocks, were measured on amphibolites, gabbros and quartz. In these places the soil contains more radioactive elements (1.5-2 ppm eU and 6-9 ppm eTh) than the rocks (0.1-0.5 ppm eU and 0.7-3.7 ppm Th), which could result from the uranium and thorium concentration during the soil genesis process and from addition of loess material.

\subsection{Seasonal variation of radon activity in the air}

It is possible to observe slight seasonal variations of radon activity in the air at a height of $2 \mathrm{~m}$ (fig. 6). In spite of the fact that the modal value is located in the same range of activity val- 
Autumn-Winter period
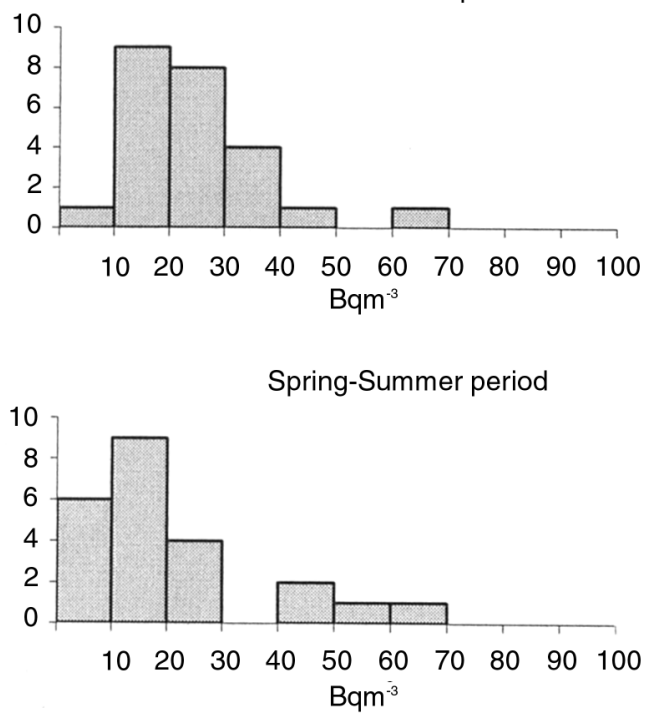

Fig. 6. Distribution of radon activity values, measured in the air $2 \mathrm{~m}$ above the ground surface in the two periods of the year, which demonstrates slight seasonal variation.

ues for the autumn-winter and spring-summer period $\left(10-20 \mathrm{Bqm}^{-3}\right)$, in the autumn-winter period there are more measurements in the range of 20-30 and 30-40 $\mathrm{Bqm}^{-3}$ than in the range of $0-10 \mathrm{Bqm}^{-3}$, the opposite situation is observed on the histogram for the spring-summer period.

The slightly higher values in the autumn-winter period could be explained by increased exhalation in the conditions of temperature difference between the air in the ground and air above the ground surface. In the autumn-winter period the air temperature above the ground usually is lower than that in the ground, which causes convection of the air from ground to the atmosphere. These phenomena were described by Wilkening (1990), Hakl et al. (1995) and Robé and Labed (1995). The snow cover, described as a factor which decreases the radon activity in the atmosphere (Juzdan et al., 1985; Somogyj et al., 1986; Feichter and Crutzen, 1989; Dörr and Münnich, 1990; Jacob and Prather, 1990; Ennemoser et al., 1995), is not the dominant factor because on this area the period of snow cover is very short.

\section{Conclusions}

The mean value of radon activity in the air $2 \mathrm{~m}$ above ground surface was $21 \mathrm{Bqm}^{-3}$. The highest values were measured in the area of granite and quartz-graphite schist outcrops (rocks of the high eU content) and in the area of mylonitic rocks of the Niemcza Zone. These observations confirm that the radon activity in the atmosphere depends on uranium/radium content in the rocks and their emanation coefficient and on the mylonitisation and fracturating grade of rocks in the tectonic zone. The slight seasonal variation of radon activity in the air is the result of weather conditions which control radon migration from soil-gas to atmosphere.

Radon activity close to the ground surface varies from 25 to $300 \mathrm{Bqm}^{-3}$ and accurately reflects the uranium and thorium content in the indirect ground basement (soil and weathered rocks).

\section{REFERENCES}

Azam, A., A.H. Naqvi and D.S. SRIVAstava (1995): Radium concentration and radon exhalation measurements using LR-115 type II plastic track detectors, Nucl. Geophys., 9 (6), 653-657.

BALL, T.K., D.G CAMERON, T.B. COLMAN and P.D. RoBERTS (1991): Behaviour of radon in the geological environment: a review, Quart. J. Eng. Geol., 24, 169-182.

BARTZ, W. and J. PuZIEWICZ (1999): Orientotion of quartz axes in the quartz-graphite schist of niemcza Zone and the Niemcz-Kamieniec Zabkowicki metamorphic unit (Lower Silesia, Poland) as an indicator of metamorphism and deformation conditions, Arch. Miner, LII (1), 113-129 (in Polish).

Cięż́owski, W. and T.A. Przylibski (1997): Radon in waters from health resorts of the Sudety Mts. (SW Poland), Appl. Radiat. Isot., 48 (6), 855-856.

DÖRR, H. and K.O. MüNNICH (1990): Rn-222 flux and soil air concentration profiles in West-Germany. Soil Rn222 as tracer for gas transport in the unsaturated soil zone, Tellus, 42B, 20-28.

Dubois, C., A. Alvarez Calleja, S. Bassot and A. ChamBAUDET (1995): Modelling the 3-dimensional microfissure network in quartz in a thin section of granite, in Gas Geochemistry, edited by C. Dubois, D. KLeIn, A. Chambaudet and M. Rebetez (Northwood: Science Reviews), 357-368.

DzIEDZICOWA, H. (1966): The schist series east of the Niemcza Zone in the light of new investigations, $Z$ geologii Ziem Zachodnich, Wroclaw, 101-118 (in Polish).

DzIEDZICOWA, H. (1987): Structural evolution and metamorphism of eastern border of the Góry Sowie, Acta Univ. Wrat. No. 788, Prace Geologiczno-Mineralogiczne, X, 221-247 (in Polish). 
Ennemoser, O., S.M.G. Giacomuzzi, P. BRunNer, P. SchneiDER, V. STIGL, F. PuRTSCHELleR and W. AMBACH (1995): Radon measurements in soil to predict indoor radon concentrations in new buildings in an area with unusually high radon levels, Sci. Total Environ., 162, 209-213.

FeICHTER, J. and P.J. CRUTZEN (1990): Parameterization of vertical tracer transport due to deep cumulus convection in a global transport model and its evaluation with Radon-222 measurements, Tellus, 42B, 100-117.

Fleischer, R.L., P.B. Price and R.M. WALKER (1965): Solid-state track detectors: applications to nuclear science and geophysics, Ann. Rev. Nuc. Sci., 15, 1-28.

Gates, A.E., L.C.S. Gundersen and L.D. Malizzi (1990): Comparison of radon in soil over faulted crystalline terranes: glaciated versus unglaciated, Geophys. Res. Lett., 17 (6), 813-816.

Gesell, T.F. (1983): Background atmospheric ${ }^{222} \mathrm{Rn}$ concentrations outdoors and indoors. A review, Health Phys., 45, 289-302.

Grasty, R.L. (1991): A cross Canada radon survey, in Proceedings of the Fifth International Symposium on the Natural Radiation Environment, Salzburg Austria.

GundERSEN, C.L.S. (1991): Radon in sheared igneous and metamorphic rocks, U.S. Geol. Surv. Bull. (on line: http://sedwww.cr.usgs.gov:8080/radon/shearl-6).

HaKL, J., I. HunYADI and A. VARHEGYI (1995): The study of subsurface radon transport dynamics based on monitoring in caves, in Gas Geochemistry, edited by C. Dubois, D. Klein, A. Chambaudet and M. Rebetez (Northwood: Science Reviews), 391-398.

JACOB, D.J. and M.J. PRATHER (1990): Radon-222 as a test of convective transport in a general circulation model, Tellus, 42B, 118-134.

JHA, S., A.H. KHAN. and U.C. Mishra (2001): A study ofthe technologically modified sources of ${ }^{222} \mathrm{Rn}$ and its environmental impact in an Indian U mineralised belt, $J$. Environ. Radioact., 53 (2), pp. 183-197.

Karamadoust, N.A., S.A. DurRani and J.H. FremLin (1988): An investigation of radon exhalation from fly ash produced in the combustion of coal, Nucl. Tracks, 15, pp. 667.

KhatiR SAM, A.K. and E. Holm (1995): The natural radioactivity in phosphate deposits from Sudan, Sci. Total Environ., 162, 173-178.

Lozano, J.C., F. Vera Tome, V. Gomez Escobar and P. BlANCO RodRIGUEZ (2000): Radiological characterization of uranium mine with no mining activity, Appl. Radiat. Isot., 53, 337-343.

MarkKanen, M. and H. Arvela (1992): Radon emanation from soils, Radiat. Prot. Dosimetry, 45 (1/4), 269-272.

Mazur, S., J. Puziewicz and D. Józefiak (1995): The Niemcza zone - A regional-scale shear zone between two areas of contrasting tectono-metamorphic evolution, in Przewodnik LXVI Zjazdu PTG «Geologia $i$ Ochrona Srodowiska Bloku Przedsudeckiego», Wrocław, 221-240 (in Polish).

OBERC-DzIEDZIC, T. (1991): Geological setting of the Strzelin granitoids, Acta Univ. Wratisl., 1375, Prace Geol. Miner., XXIX, pp. 295-324 (in polish).

ObERC-DZIEDZIC, T. and J. SzCZEPAŃSKI (1995): Geology of the Wzgórza Strzelińskie cristalline massif, in Przewodnik LXVI Zjazdu PTG «Geologia $i$ Ochrona Środowiska Bloku Przedsudeckiego», Wrocław, 111-126 (in Polish).

PAPASTEFANOU, C. (2001): Radiological impact from atmospheric releases of ${ }^{238} \mathrm{U}$ and ${ }^{226} \mathrm{Ra}$ from phosphate rock processing plants, J. Environ. Radioact., 54, pp. 75-83.

PuzIEwicz, J. and M. RadKowska (1990): Morphology of the crystals of zircon from plutonic rocks of the Niemcza Zone (Sudetes, SW Poland), Arch. Miner, XLVI (1-2), 124-139 (in Polish).

RoBé, M.C. and V. LABED (1995): Explaining the variation in soil radon concentrations: a study of the influence of some intrinsic properties of a rock matrix on the radon emission factor, in Gas Geochemistry, edited by C. Dubois, D. Klein, A. Chambaudet and M. Rebetez (Northwood: Science Reviews), 535-542.

SolECKI, A.T. (1999): Radon emanation of selected Sudetic rocks, in 5th International Conference on Rare Gas Geochemistry, August 30-September 3, 1999, Debrecen, Hungary.

SolECKI, A.T. (2000): Radiometric anomalies of the central part of the Sudetic Foreland and their relation with geological environment, Acta Univ. Wrat. No. 2210, Prace Geologiczno-Mineralogiczne, LXIX, 1-91 (in Polish).

Somogyj, G., A.F. Hafez, I. Hunyadi and M. Tóth-SzILÁGYJ (1986): Measurement of exhalation and diffusion parameters of radon in solids by particle track detectors, Int. J. Radiat. Appl. Instrum., Part D, Nucl. Tracks Radiat. Meas., 12 (1/6), 701-704

Srivastava, D.S., P. Singh, N.P.S. Rana, A.H. Naqvi, A. Azam, T.V. RamachandRan and M.C. Subba RAMU (1995): Calibration factor for LR-115 type II track detectors for environmental radon measurements, $\mathrm{Nucl}$. Geophys., 9 (5), 487-495.

STRZELECKI, R. and S. WolkowiCz (1993): Geological control on radon emanations, Nukleonika, 38 (4), 109-120.

Wilkening, M. (1990): Radon in the environment, Studies in Environmental Science No. 40, pp. 138.

WoJNAR, B. (1977): Petrography of granite from Górka Sobocka in the Foresudetic block, Acta Univ. Wrat. No. 378, Prace Geologiczno-Mineralogiczne, VI, 139-156 (in Polish). 